\title{
Small scale market survey on the preparation and physico-chemical characterstics of moin-moin: a traditional ready-to-eat cowpea food from Brazil
}

\author{
Lafaiete Almeida CARDOSO ${ }^{*}$ (D) , Ralf GREINER ${ }^{2}$, Cíntia de Santana SILVA³, Leonardo Fonseca MACIEL ${ }^{4}$, \\ Luis Fernandes Pereira SANTOS 3 , Deusdélia Teixeira de ALMEIDA ${ }^{3}$
}

\begin{abstract}
Preparation practices and physicochemical characteristics of moin-moin commercialized in Salvador (Brazil) as a street food by typically clothed women called baianas de acarajé were studied. Four moin-moin samples were collected from each of the thirty sales points included in the study and analyzed for moisture, protein, fat, ash, carbohydrates, fiber, total carotenoids, weight, color and texture. The ingredients used for the preparation of moin-moin were as follows: grated dry shrimp heads (100.0\%), grated onions (96.7\%), salt (73.3\%), Crude Palm Oil (53.3\%) or Crude Palm Olein (46.7\%) and garlic (16.7\%). Peanut, codfish, cashew nuts, wheat flour, ginger and tomatoes are further ingredients frequently used. Texture analysis revealed that moin-moin is a soft, fragile and brittle food product. The content of total carotenoids ranged from 6.99 to $64.88 \mathrm{ppm}$ with an average value of $28.49 \pm 4.00 \mathrm{ppm}$, giving the product an ocher-orange/yellow-orange color. An average sized moin-moin ball (186.6 g) contained $14.08 \%$ protein, $13.08 \%$ lipids, $30.83 \%$ carbohydrates, $4.01 \%$ fiber and $297.42 \mathrm{kcal}$, corresponding to $18.77 \%$, $23.78 \%, 10.28 \%$ and $14.87 \%$ of the daily requirements of an adult for protein, lipids, carbohydrates and energy, respectively.
\end{abstract}

Keywords: moin-moin; preparation practices; physicochemical characteristics; baianas de acarajé; crude palm oil; street food; cowpea (Vigna unguiculata).

Practical Application: Moin-moin, or steamed cowpea paste, is a traditional ready-to-eat cowpea food from Brazil. The consumption of a medium-sized moin-moin ball $(186.6 \mathrm{~g})$ meets $18.77 \%, 23.78 \%, 10.28 \%$ and $14.87 \%$ of the daily requirements of an adult for protein, lipid, carbohydrates and energy, respectively. The knowledge gained about the link between ingredients used for moin-moin preparation, the preparation techniques applied and the final composition of moin-moin may contribute to improve is quality with positive effects on the health status of the consumers.

\section{Introduction}

Moin-moin or moyi-moyi is a traditional African street food obtained by steaming a homogeneous paste containing cowpea (Vigna unguiculata), vegetable oil, pepper and other ingredients (Oguntona et al., 1999; Ayoade et al., 2012; Akajiaku et al., 2014). It is called abará, abala or olelé in Brazil and is a cultural and touristic icon in the city of Salvador (Brazil) sold in the streets every day by typically clothed women called baianas de acarajé (Instituto do Patrimônio Histórico e Artístico Nacional, 2005; Borges, 2008). Moin-moin represents an important source of income for the saleswomen. Like akara (fried cowpea paste) (Feitosa et al., 2015), moin-moin is prepared with several varieties of cowpeas (Vigna unguiculata L.Walp) such as fradinho, macássar, olho de pombo, costela de vaca and boca preta (Rogério et al., 2014).

The traditional preparation of moin-moin involves cowpea soaking to soften the teguments. It is manually removed and separated from the cotyledons by floating in water. Thereafter, the cotyledons are grinding to form a paste. Finally, further ingredients (grated onions, salt, grated dry shrimp heads, crude palm oil (CPO) or crude palm olein (CPOL), cashew nut, peanut, and ginger) are dispersed homogeneously throughout the cowpea paste. The mixture is shaped into balls with a wooden spoon, wrapped with banana leaves and steaming for how long (Borges, 2008; Rogério et al., 2014). In Bahia, this steamed cowpea paste is served with some local culinary and cultural dishes such as vatapá, caruru, dry shrimps, vinaigrette salad and pepper sauce.

Cowpeas are characterized by a high proportion of complex carbohydrates (50.4-65.8\%), such as resistance starch, stachyose (17-60\%), verbascose (6-13\%), and raffinose (5-10\%). Their protein content was reported to be 20.3-39.4\%. Cowpea protein has a good nutritional quality, but is low in methionine (Carvalho et al., 2012; Gonçalves et al., 2016). Cowpeas are an important protein source in countries such as Africa, Asia and South America, however they are in contrast to animal protein cheap and well accessible (Rogério et al., 2014; Feitosa et al., 2015; Gonçalves et al., 2016). With about 3\%, cowpeas are low in fat and the major fatty acids present are palmitic (20.5-67.1\%), linoleic (20.8-40.3\%), linolenic (9.6-30.9\%), and stearic acid (2.9-14.0\%). In addition, cowpeas represent a good source of complex B vitamins (niacin, pantothenic acid, thiamine) and minerals such as potassium (957-1225 mg/100 g), magnesium

${ }^{1}$ Departamento de Química Orgânica, Instituto de Química, Universidade Federal da Bahia - UFBA, Salvador, BA, Brasil

${ }^{2}$ Department of Food Technology and Bioprocess Engineering, Federal Research Institute of Nutrition and Food, Max Rubner Institut, Karlsruhe, Germany

${ }^{3}$ Departamento de Ciências dos Alimentos, Escola de Nutrição, Universidade Federal da Bahia - UFBA, Salvador, BA, Brasil

${ }^{4}$ Departamento de Análises Bromatológicas, Faculdade de Farmácia, Universidade Federal da Bahia - UFBA, Salvador, BA, Brasil

*Corresponding author: lafaiete@ufba.br 
(130-160 mg/100 g), manganese (1.7-2.9 mg/100 g), phosphorus (345-673 mg/100 g), calcium (38.3-1062 mg/100 g), iron (6.0-8.1 mg/100 g), and zinc (2.7-4.4 mg/100 g) (Carvalho et al., 2012; Gonçalves et al., 2016; Organization for Economic Co-operation and Development, 2018).

However, the nutritional quality of cowpeas is reduced due to the presence of anti-nutrients, such as phytates, trypsin inhibitors, hemagglutinins, polyphenols and tannins (Jayathilake et al., 2018). Phytates, polyphenols and tannins especially are reported to reduce the bioavailability of minerals and trace elements such as iron, zinc, copper, calcium and magnesium due to the formation of insoluble or very poorly dissociated complexes (Feitosa et al., 2015). The nutritional quality of cowpeas was shown to be improved after the application of processing technologies such as soaking, germination, fermentation, steaming, baking and extrusion (Feitosa et al., 2018).

Crude palm oil is an important part of the Brazilin cuisine and is characterized by a balanced fatty acid composition (Almeida et al., 2013). With 40\% oleic acid, 10\% linoleic acid, $45 \%$ palmitic acid, and 5\% stearic acid, it contains almost equal amounts of saturated and unsaturated fatty acids (Almeida et al., 2013). In addition, crude palm oil contains minor components (1\%) such as carotenoids (500-700 ppm), responsible for its dark orange color (Food and Agriculture Organization, 2017; Almeida et al., 2019). Some carotenoids, for example $\beta$-carotene, are capable of being converted into vitamin A, thereby playing an important nutritional role (Grune et al., 2010). A liquid fraction (crude palm olein (CPOL)) rich in unsaturated compounds and a solid fraction (palm stearin) rich in saturated compounds are derived from crude palm oil by fractionation.

So far, only a very few studies have been conducted on moin-moin. Therefore, a study was carried out to improve the knowledge of the preparation process of moin-moin, the selection of the ingredients used and the effects of the different ingredients, as well as the preparation process on the properties of moin-moin such as composition, color and texture. Texture and appearance are two important characteristics of food, affecting its selection and consumption by consumers. The protein and starch content of cowpeas are very likely important contributors to the characteristic texture of moin-moin and its orange color is mainly derived from the carotenoid content of the crude palm oil or crude palm olein used for its preparation. Thus, this study aims to obtain information on the preparation of good quality moin-moin and estimate its contribution to the intake of energy and selected nutrients.

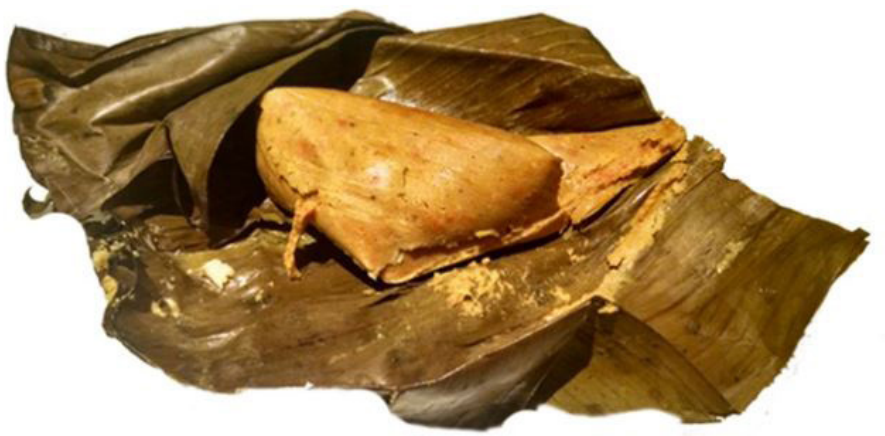

\section{Materials and methods}

\subsection{Study site and sampling}

Four moin-moin balls per sample point wrapped in banana leafs (Figure 1) were collected from 30 (18\%) of the 168 moinmoin sales points in the districts Barra-Rio Vermelho and Centro Histórico, the most important tourist areas of the city of Salvador, Brazil. They were immediately transferred to freezer storage bags and transported in insulated boxes to the laboratory. On the same day, the samples were analyzed for mass, moisture, color and texture.

\subsection{Determination of moisture content}

Moisture content was determined according to the AOAC method (Association of Official Analytical Chemists, 2000); $3 \mathrm{~g}$ of moin-moin balls were dried to constant mass at $105^{\circ} \mathrm{C}$ for 12 hours.

\subsection{Color measurement}

The color of moin-moin balls was measured using $2 \mathrm{~mm}$ quartz cells in a Chroma Meter CR-400 (Konica Minolta Sensing Inc., Japan) with $\mathrm{D}_{65}$ illuminant under an angle of $2^{\circ}$ at $22-24^{\circ} \mathrm{C}$. The following parameters were determined: lightness $\left(\mathrm{L}^{*}\right)$, redgreen characteristics $\left(\mathrm{a}^{\star}\right)$ and blue-yellow characteristics $\left(\mathrm{b}^{\star}\right)$. Hue angle $\left(\mathrm{h}_{\mathrm{ab}}\right)$ and chroma $\left(C^{\star}\right)$ were calculated as follows: $h_{a b}=\tan ^{-1}\left(b^{\star} / a^{\star}\right), C^{\star}=\left[\left(a^{\star 2}+b^{\star 2}\right)^{1 / 2}\right]$. Color differences $(\Delta \mathrm{E})$ between the external surface and interior of the moin moin balls were calculated as follows: $\left.\Delta E=\left.\left\{\left(L_{s}-L_{i}\right)^{2}+\left(a_{s}-a_{i}\right)^{2}+\left(b_{s}-b_{i}\right)^{2}\right\}^{1}\right|^{2}\right)$, where the color parameters of the surface are indicated by the subscript $s$ and the color parameters of the internal by subscript i. Color measurements were performed in five and four independent determinations at the surface and interior, respectively, for each moin-moin ball (Andreu-Sevilla et al., 2008).

\subsection{Instrumental texture profile analysis (two-cycle compression test)}

Texture analysis was performed in a TA-TX EXPRESS texture analyzer (Stable Micro Systems Ltd., Surrey, UK), equipped with a $10 \mathrm{~kg}$ load cell. A $75 \mathrm{~mm}$ diameter compression plate was used to compress the $1.8 \mathrm{~cm} \times 2.2 \mathrm{~cm}$ (diameter $\times$ height) moin moin samples. The TPA settings were as follows: pre-test speed: $1.0 \mathrm{~mm} / \mathrm{s}$; test speed: $1.0 \mathrm{~mm} / \mathrm{s}$; post-test speed: $1.0 \mathrm{~mm} / \mathrm{s}$; target mode distance: $5 \mathrm{~mm}$; trigger force: $5 \mathrm{~g}$; trigger type: auto. The delay between the first and second compression was $5 \mathrm{~s}$. A

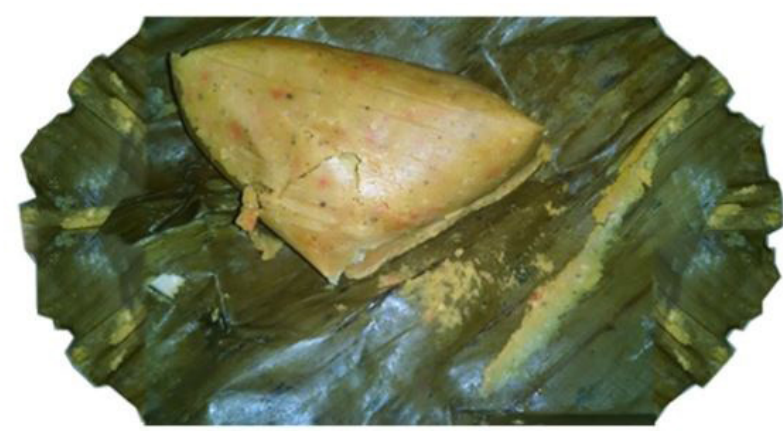

Figure 1. Moin-moin sample collected from a sales point in the city of Salvador-Bahia. 
force-time graph was generated and textural parameters, such as hardness, cohesiveness, adhesiveness, springiness, resilience, gumminess and chewiness, were calculated with the help of the software provided along with the instrument. Each moin moin ball was measured in duplicate.

\subsection{Composition analysis of moin-moin balls}

In order to obtain compositional data of moin-moin, all samples were freeze-dried (Freeze-dryer LS 3000 D, Terroni Equipamentos Científicos Ltda., Brazil) after keeping the samples for 24 hours at $-80^{\circ} \mathrm{C}$. The dry samples were ground in a domestic stainless-steel food processor (Cuisinart Coffee Grinder, Model DCG-20) and the ground material was stored in amber bottles at $-20^{\circ} \mathrm{C}$ for further analysis.

The Kjeldahl method was applied to quantify crude protein (Association of Official Analytical Chemists, 2000) using $\mathrm{N} \times 6.25$ for the calculation. Crude fat was determined by extraction with petroleum ether (boiling point $30-60{ }^{\circ} \mathrm{C}$ ) in a goldfish apparatus (Association of Official Analytical Chemists, 1995). Ash was determined by heating the sample to $550{ }^{\circ} \mathrm{C}$ for 10 hours (Association of Official Analytical Chemists, 1997). Fiber content was obtained according to Goering \& Van Soest (1970) and Van Soest et al. (1991), using an automatic fiber analyzer (A-220, ANKON, New York, USA). All determinations were performed in triplicate. The content in total carbohydrate was calculated considering the contents of moisture, protein, fat and ash. Energy content of moin-moin was calculated from the content of total carbohydrates or crude protein multiplication with $4 \mathrm{kcal} / \mathrm{g}$ and crude fat per $9 \mathrm{kcal} / \mathrm{g}$ (Brasil, 2003).

Total carotenoids were determined as described by Souza et al. (2012), with modifications. Two grams of freeze-dried sample were extracted with $50 \mathrm{~mL}$ cold acetone. Any particulate matter was removed by filtration. The solid residue was washed with acetone until complete loss of color. The combined acetone solutions (about $65 \mathrm{~mL}$ ) were mixed with cold petroleum ether $(50 \mathrm{~mL})$ and the acetone was removed with ultrapure water (Milli-Q-Millipore). The absence of acetone was confirmed with 2,4-dinitrophenylhydrazine. After saponification with methanolic $\mathrm{KOH}(10 \%, \mathrm{w} / \mathrm{v})$, the extract was washed with ultrapure water (Milli-Q-Millipore) until a $\mathrm{pH}$ value close to 7 was obtained. Thereafter, the extract was dried over anhydrous sodium sulfate. Finally, absorbance of the extract at $450 \mathrm{~nm}$ was determined and carotenoid content was calculated as follows (Rodriguez-Amaya \& Kimura, 2004; Equation 1):

Total carotenoid content $(\mu \mathrm{g} / \mathrm{g})=\mathrm{A} \times \mathrm{V} \times 10^{4} / \mathrm{A}_{1 \mathrm{~cm}}^{1 \%} \times \mathrm{m}$

where $\mathrm{A}=$ absorbance; $\mathrm{V}=$ total volume of extract in $[\mathrm{mL}]$; $\mathrm{A}_{1 \mathrm{~cm}}^{1 \%}=$ absorption coefficient of $\beta$-carotene in petroleum ether (2592); $\mathrm{m}=$ mass of the sample in $[\mathrm{g}]$.

Carotenoid measurements were performed in triplicate.

\subsection{Collecting information about the preparation of moin- moin}

While collecting the samples, the saleswomen (baianas de acarajé) were invited to complete a structured questionnaire about the selection of the cowpea variety used and the preparation process applied (Table 1). Each participant in the questionnaire provided informed consent, which had previously been approved by the Ethics Committee of the School of Nutrition of Federal University of Bahia (Protocol 730.192/2014).

\subsection{Statistical analysis}

Data was analyzed using the SPSS 13 software (SPSS Inc. Chicago, Il, USA). Color measurements were performed in five and four independent determinations at the surface and interior, respectively. Texture was analyzed in duplicate, the others in triplicate, and values were given as mean \pm standard deviation (SD). The correlation between composition data and color was assessed by Spearman's rank correlation test.

Table 1. Most important information derived from the questionnaire about the selection of the cowpea variety used and the preparation process for moin-moin applied.

\begin{tabular}{|c|c|}
\hline Questions & (Number) \% \\
\hline Fradinho & (12) 40.0 \\
\hline Macáçar & (8) 26.7 \\
\hline Olho de Pombo & (3) 10.0 \\
\hline More than one variety & (5) 16.7 \\
\hline Not applicable (ready-to-use cowpea paste was bought) & (2) 6.7 \\
\hline \multicolumn{2}{|l|}{ What about the color of the cowpeas bought? } \\
\hline Light & (23) 76.7 \\
\hline Either light or dark & (1) 3.3 \\
\hline No preference & (4) 13.3 \\
\hline Ready-to-use cowpea paste bought & (2) 6.7 \\
\hline \multicolumn{2}{|l|}{ Soaking Time (h) } \\
\hline$<1$ & (5) 16.7 \\
\hline $1-2$ & (13) 43.3 \\
\hline $2-4$ & (8) 26.7 \\
\hline $4-6$ & (2) 6.7 \\
\hline Ready-to-use cowpea paste bought & (2) 6.7 \\
\hline \multicolumn{2}{|l|}{ Were hulled or dehulled cowpeas bought? } \\
\hline Dehulled & (17) 56.7 \\
\hline Hulled & (11) 36.7 \\
\hline Ready-to-use cowpea paste bought & (2) 6.7 \\
\hline \multicolumn{2}{|l|}{ Which ingredients were added to the cowpea paste? } \\
\hline Grated dry shrimp heads & (30) 100.0 \\
\hline Grated Onions & (29) 96.7 \\
\hline Salt & (22) 73.3 \\
\hline Crude palm oil & (16) 53.3 \\
\hline Olein palm oil & (14) 46.7 \\
\hline Garlic & (5) 16.7 \\
\hline $\begin{array}{l}\text { Others (cashew nuts, codfish, ginger, peanuts, tomatoes, } \\
\text { wheat flour) }\end{array}$ & (19) 63.3 \\
\hline \multicolumn{2}{|l|}{ What was the treatment of the banana leaves? } \\
\hline Burning the leaves over a fire & (14) 46.7 \\
\hline Sanitization (sodium hyploclorite) & (14) 46.7 \\
\hline Passing the leaves through boiling water & (7) 23.3 \\
\hline $\begin{array}{l}\text { Others (passing the leaves into a hot dish cloth, passing } \\
\text { the leaves into a dish cloth) }\end{array}$ & (11) 36.7 \\
\hline
\end{tabular}




\section{Results and discussion}

\subsection{Preparation practices}

According to the interviews, different bean varieties were used for moin-moin preparation: fradinho (40.0\%), macássar (26.7\%), and olho de pombo (10.0\%) (Table 1). In addition, $16.7 \%$ of the saleswomen (baianas de acarajé) used more than one bean variety for the preparation of moin moin. $60 \%$ of the saleswomen soaked the cowpeas for at maximum 2 hours at room temperature (Table 1 ).

Thus, the soaking time applied is shorter than that for other seed beans (Derivi et al., 2006; Fernandes, 2010; Fernandes et al., 2011). The lower grain length/width ratio of cowpeas compared to the other seed beans might explain that less time is required for complete soaking. Beans with lower ratios normally absorb less water than beans with high ratios (Chiaradia \& Gomes, 1997).

In order to prepare the cowpea paste, dehulled beans were used by the saleswomen. Some saleswomen (56.7\%) already bought dehulled cowpeas and some (36.7\%) performed the dehulling process on their own (Table 1 ). The minority of the saleswomen $(6.7 \%)$ bought a ready-to-use cowpea paste. For the grinding process, in order to obtain the cowpea paste, grinding stones were traditionally used by the baianas de acarajé. The traditional grinding stones were replaced in the meantime by electric wet grinders (Borges, 2008; Santos, 2013; Rogério et al., 2014), resulting in an easier and faster grinding process.

The following ingredients were used by the baianas de acarajé for the preparation of moin-moin: grated dry shrimp heads $(100.0 \%)$, grated onions $(96.7 \%)$, salt $(73.3 \%)$, CPO (53.3\%) or CPOL (46.7\%) and garlic (16.7\%) (Table 1). Peanut, codfish, cashew nuts, wheat flour, ginger and tomatoes are further ingredients frequently used. After being incorporated into the cowpea paste, the mixture was shaped into balls with a wooden spoon, wrapped with banana leaves (Musa sp) and steamed. The leaves used as wrappings were cleaned by different procedures by the baianas de acarajé (Table 1). Wrapping the moin-moin balls with banana leaves should protect the moinmoin constituents during steaming and storage. Due to the large surface area, the flexibility and the waxy nature of banana leaves, air flow into the wrapped food is possible. In addition, a unique flavor is added to the product (Maidin \& Latiff, 2015), in part due to the migration of banana leaf polyphenols to the product (Cushnie \& Lamb, 2005).

The mass of the moin-moin balls collected in this study was between 131.0 and $266.3 \mathrm{~g}$, with an average value of $186.61 \pm 29.74 \mathrm{~g}$. The mass of the banana leaf used as a moinmoin wrapping varied between 11.2 and $50.0 \mathrm{~g}$, with an average value of $26.8 \pm 9.0 \mathrm{~g}$.

\subsection{Chemical characteristics}

Although moin-moin represents the second most commercialized food product by the baianas de acarajé (Borges, 2008), there are no data on its composition in the Brazilian Food Composition Database (Instituto Brasileiro de Geografia e Estatística, 1999; Franco, 2008; Universidade Estadual de Campinas, 2011). The protein content of moin-moin balls was determined to be in the range of 4.3 to $12.3 \%$ (w/w wet matter) (Table 2 ) and $60 \%$ of the moin-moin samples showed values between 4 and $7 \%$ (w/w wet matter), significantly lower than those observed in cowpea seeds (Carvalho et al., 2012; Gonçalves et al., 2016). This is due to the use of ingredients free or low in protein (Ikechukwu et al., 2018), removal of the teguments, cowpea dehulling and processing steps such as soaking and steaming (Carvalho et al., 2012). A reduction in protein content and an increase in protein digestibility is a common observation upon bean processing. The protein content of the moin-moin balls obtained in this study is in good agreement with those already reported: $7.7 \%$ (w/w wet matter) (Ikechukwu et al., 2018), 12.04\% (w/w wet matter) (Sanusi \& Olurin, 2012), 4.4\% (w/w wet matter) (Ogundele et al., 2015), and $7.6-11.9 \%$ (w/w wet matter) (Chinaza et al., 2019).

The removal of the cowpea tegument and the wet grinding process resulted in a reduced particle size, favoring the formation of a smooth paste high in moisture (Kethireddipalli et al., 2002; Singh et al., 2003). The high moisture content of moin-moin (Table 2) also leads to its low shelf life (Owuamanam et al., 2013; Otunola \& Afolayan, 2018). Although macromolecules such as starch and pectic substances contribute to water absorption, the major water-imbibing moin-moin constituents are proteins. Shakpo \& Osundahunsi (2016) demonstrated that the substitution of cowpeas by maize in blend flours increased the water and oil binding capacities, as well as foaming capacity, emulsion capacity and stability.

Carbohydrates have been identified as the major constituents of cowpeas and moin-moin (Table 2). The carbohydrate content of moin-moin ranged from $11.06 \%$ to $28.74 \%$ (w/w wet matter) (Table 2). The addition of refined wheat flour to the cowpea mass (Table 1) resulted in higher carbohydrate contents of the moin-moin balls, as reported by some baianas de acarajé, with a consequent reduction in the protein contents and a concomitantly decreased oil absorption capacity (Malomo et al., 2017). Dehulled cowpeas contain about $18 \%$ (w/w dry matter) fiber and the ratio of soluble and insoluble fibers was reported to be 1:4.5 (Khan et al., 2007). Since ingredients such as nuts and peanuts also provide fiber $(3.7 \%$ and $7.8 \%$, respectively, (Universidade Estadual de Campinas, 2011) and removal of the tegument resulted in a loss of a large part of the insoluble fiber

Table 2. Proximate composition of moin-moin sold in the city of Salvador-Bahia.

\begin{tabular}{lcc}
\hline \multicolumn{1}{c}{ Parameter } & $\begin{array}{c}\text { Content } \\
\text { (Wet matter) }\end{array}$ & Mean \pm SD \\
\hline Moisture (\% w/w) & $54.13-71.31$ & $64.91 \pm 1.28$ \\
Ash (\% w/w) & $1.16-3.03$ & $1.88 \pm 0.20$ \\
NDF (\% w/w) & $1.08-3.15$ & $1.75 \pm 0.30$ \\
ADF (\% w/w) & $0.05-1.03$ & $0,40 \pm 0.13$ \\
Fat $(\% \mathrm{w} / \mathrm{w})$ & $3.60-13.19$ & $7.01 \pm 1.06$ \\
Proteins $(\% \mathrm{w} / \mathrm{w})$ & $4.31-12.32$ & $7.55 \pm 0.35$ \\
Carbohydrates $(\% \mathrm{w} / \mathrm{w})$ & $11.06-28.74$ & $16.52 \pm 1.72$ \\
TC $(\mathrm{ppm})$ & $6.99-64.88$ & $28.49 \pm 4.00$ \\
Energy $(\mathrm{kcal})$ & $120.96-198.78$ & $159.39 \pm 6.77$ \\
\hline NDF = neutral detergent fiber; ADF $=$ detergent acid fiber; TC = total \\
carotenoids; SD = standard deviation. Number of moin-moin samples \\
analyzed: 30. All samples were analyzed in triplicate.
\end{tabular}


fraction (Khan et al., 2007), the soluble to insoluble fiber ratio was much higher than in the cowpeas (Table 2).

Compared to oil seeds such as soybeans (18.15-19.04\%), cowpeas are rather low in fat (3\%) (Ciabotti et al., 2016). Ingredients such as peanuts, cashew nuts, $\mathrm{CPO}$ or CPOL are responsible for the relative high fat content of moin-moin (Table 2). The baianas de acarajé use CPO or CPOL in varying amounts for the preparation of moin-moin (Table 1). In 20, 73 and $7 \%$ of the moin-moin samples, $1-4 \%, 5-9 \%$ and more than $10 \%(\mathrm{w} / \mathrm{w}$ wet matter) of fat, respectively, was determined.

$\mathrm{CPO}$ is the world's richest source of natural plant carotenoids in terms of retinol (pro-vitamin A) equivalents. The Codex Alimentarius (Food and Agriculture Organization, 2017) indicates the levels of total carotenoids in CPO between 500 and $2000 \mathrm{ppm}$. The concentration of total carotenoids in the moinmoin samples analyzed was found to be 6.99 to $64.88 \mathrm{ppm}$ wet matter, with an average value of $28.49 \pm 4.00 \mathrm{ppm}$ wet matter (Table 2). The variation in total carotenoid content reflected the type (CPO or CPOL) and amount of oil added to the crude cowpea paste. Furthermore, $\mathrm{CPO}$ contributes to the orange color of the moin-moin balls (Andreu-Sevilla et al., 2008; Almeida et al., 2013). Since the grated dry shrimp heads added to the crude cowpea paste contain astaxanthin, they also contribute to the color of the moin-moin balls and act as a source of carotenoids (Martínez-Delgado et al., 2017).

The average value of the ash content was found to be $1.88 \pm 0.20 \%$ (w/w wet matter) (Table 2 ). The variability of the ash content of moin-moin is relatively low and only one sample showed an ash content above 3\%. The ash content of cowpea seeds was reported to be 3-4\% (Ikechukwu et al., 2018). The lower ash contents of moin-moin might be due to the soaking and dehulling process. Both processes remove either manually or by leaching a significant part of the minerals present in cowpeas (Ikechukwu et al., 2018).

The energy content of the moin-moin samples collected in Salvador (120.96-198.78 kcal) was comparable to those of moin-moin produced in Nigeria. Energy contents from 148.08 to $158.64 \mathrm{kcal}$ (Ikechukwu et al., 2018) and $198.3 \mathrm{kcal}$ (Sanusi \& Olurin, 2012), respectively, were reported for the Nigerian moin-moin.

Considering the weight of an average moin-moin ball (186.6 g), the mean values for protein, lipid, carbohydrates, fiber and energy were $14.08 \%(\mathrm{w} / \mathrm{w}), 13.08 \%(\mathrm{w} / \mathrm{w}), 30.83 \%(\mathrm{w} / \mathrm{w})$, $4.01 \%(\mathrm{w} / \mathrm{w})$ and $297.42 \mathrm{kcal}$. These values correspond to $18.77 \%$, $23.78 \%, 10.28 \%$ and $14.87 \%$ of the daily requirements of an adult for protein, lipid, carbohydrates and energy, respectively (Brasil, 2005). In addition, moin-moin can serve as a good source of pro-vitamin A, a micronutrient of public health significance in Salvador, as approximately $27.5 \%$ of the students had retinol values $<30 \mu \mathrm{g} / \mathrm{dL}$ (Ribeiro-Silva et al., 2014).

\subsection{Color characteristcs (CIELab) of moin-moin}

The color of the external surface of the moin-moin balls varied between yellow/oche, orange and bronze, while the interior was characterized by a saturated ocher-orange/yellow-orange color (Table 3). Using the mean values, the color difference $(\Delta \mathrm{E})$ between the surface and the interior was calculated to be $18.29^{\circ}$. According to Adekunte et al. (2010), differences in the perceived color $(\Delta \mathrm{E})$ can be classified as very big $(\Delta \mathrm{E}>3)$, big $(1.5<\Delta \mathrm{E}<3)$ and small $(1.5<\Delta \mathrm{E})$. The big color difference between the surface and the interior of the moin-moin balls could also be easily seen (Figure 1).

The lower color intensity of the surface, compared to the interior of the moin-moin balls, could be explained by the transfer of a wax (melting point $79.01-81.38^{\circ} \mathrm{C}$ ) with a white/ greenish yellow color from the banana leaves to the surface of the moin-moin balls (Charumanee et al., 2017).

$\mathrm{CPO}$ and $\mathrm{CPOL}$ carotenoids were considered as the main contributors to the color of the moin-moin balls. A better correlation between TC and $\mathrm{C}^{*}(\mathrm{r}=0.463, \mathrm{p}<0.05)$ and $\mathrm{b}^{*}$ $(\mathrm{r}=0.470, \mathrm{p}<0.05)$ values were obtained for the interior compared to the surface $\left(C^{*}: r=0.410, p<0.05 ; b^{*}: r=0.394\right.$, $\mathrm{p}>0.05)$. The above-mentioned transfer of the wax from the banana leaves to the surface of the moin-moin balls might also explain the worse correlation. Furthermore, the cowpea variety used for the preparation of moin-moin (Frank-Peterside et al., 2002), as well as the addition of other ingredients such as the grated dried shrimp heads, affect the color of the final product.

\subsection{Texture profile analysis of moin-moin}

Texture parameters such as hardness, adhesiveness, chewiness, springiness, gumminess, cohesiveness, and resilience were obtained by textural profile analysis (TPA) (Table 4). Texture parameters showed a wide variation among the moin-moin

Table 3. Color (CIELab) profile analysis of external and internal surfaces of moin-moin balls sold in the city of Salvador-Bahia.

\begin{tabular}{lrrrrrrrr}
\hline \multirow{2}{*}{ Color } & \multicolumn{3}{c}{ External Surface } & & \multicolumn{3}{c}{ Internal Surface } \\
\cline { 2 - 4 } \cline { 6 - 8 } & Min. & Max. & Mean \pm SD & & Min. & Max. & Mean \pm SD \\
\hline $\mathrm{L}^{*}$ & 47.45 & 65.85 & $54.01 \pm 4.3$ & & 49.08 & 67.02 & $56.89 \pm 4.4$ \\
$\mathrm{a}^{*}$ & 3.11 & 12.87 & $8.41 \pm 2.3$ & & 8.20 & 19.85 & $12.94 \pm 3.0$ \\
$\mathrm{~b}^{*}$ & 24.51 & 48.74 & $34.81 \pm 6.3$ & & 39.66 & 72.07 & $52.30 \pm 4.3$ \\
$\mathrm{C}^{*}$ & 26.37 & 49.78 & $35.88 \pm 6.0$ & & 42.92 & 73.21 & $54.86 \pm 8.3$ \\
$\mathrm{~h}_{\mathrm{ab}}\left({ }^{\circ}\right)$ & 64.39 & 86.25 & $76.00 \pm 4.7$ & & 63.14 & 82.46 & $75.79 \pm 4.8$ \\
\hline
\end{tabular}

Mean \pm standard deviation. $L^{*}=$ Lightness $(0=$ black, $100=$ white $),+a^{*}=$ red, $-\mathrm{a}^{*}=$ green, $+\mathrm{b}^{*}=$ yellow, $-\mathrm{b}^{*}=$ blue, $\mathrm{h}_{\mathrm{ab}}=$ hue angle, $\mathrm{C}^{*}=$ chroma. Number of moin-moin samples: 30 , color measurements were performed in quadruplicate.

Table 4. Texture profile Analysis (N) of moin-moin balls sold in the city of Salvador-Bahia.

\begin{tabular}{lccc}
\hline & Minimum & Maximum & Mean \pm SD \\
\hline Adhesiviveness & -9.98 & 9.25 & $-1.79 \pm 3.25$ \\
Cohesiveness & 0.70 & 0.82 & $0.77 \pm 0.03$ \\
Chewiness & 174.06 & 1263.58 & $561.20 \pm 264.78$ \\
Gumminess & 211.05 & 1364.26 & $615.07 \pm 290.19$ \\
Hardness & 303.10 & 1800.08 & $801.37 \pm 378.69$ \\
Resilience & 0.38 & 0.51 & $0.45 \pm 0.04$ \\
Springness & 0.82 & 1.06 & $0.91 \pm 0.05$ \\
\hline
\end{tabular}

Number of moin-moin samples: 30 , measurements were performed in quadruplicate. $\mathrm{SD}=$ standard deviation 
samples. The use of different cowpea varieties and differences in the type and amount of further ingredients used, as well as differences in the preparation process, might explain these big differences (Enwere \& Hung, 2000).

Differences in the gelatinization pattern of starch and the susceptibility of the cell constituents, notably the protein matrix, may contribute to the overall textural characteristics of legumes and their products. Textural characteristics of moin-moin depend upon both, the bean microstructure and chemical and/or physical changes occurring during processing (Singh et al., 2004). Cellular structures and fibers can be destroyed by milling. In addition, more extensive starch degradation might occur, causing a weak association of amylose and amylopectin, leading to increased stiffness (McWatters, 1983; Malomo et al., 2017).

Hardness represents the firmness of moin-moin products and was positively correlated with gumminess $(r=0.996$, $\mathrm{p} \leq 0.05)$ and chewiness $(\mathrm{r}=0.984, \mathrm{p} \leq 0.05)$, respectively. Thus, moin-moin can be classified as a soft product with fragile and brittle composition. Enwere \& Hung (2000) reported that drying temperature, wet milling and the addition of ingredients such as salt, onions, and oil decreased the hardness of moin moin. Ossai et al. (1987) found a decrease in hardness of moin-moin with increasing oil contents. Considering that starch and $\mathrm{CPO}$ are the major constituents of moin-moin, softening may be related to the formation of amylose-lipid complex and the stabilization of amylose in the helical form (Ossai et al., 1987). Thus, differences in the $\mathrm{CPO}$ or CPOL content of moin-moin very likely contribute to the differences observed in texture characteristics.

Malomo et al. (2017) described moin-moin as a soft product with a characteristically smooth and moisty mouth feel. In this study, the high values for gumminess (Table 4) were in accordance with that description. Moin-moin was reported to be a gel produced by heating a paste containing cowpea solids of $15 \%$ and above (Akusu \& Kiin-Kabari, 2012). Thus, the high amylose content of cowpea starch could be responsible for producing a gel with high gumminess values.

Due to the low values for springiness, resilience (stickiness) and cohesiveness (Table 4), moin-moin represented a product with low elasticity. Those parameters therefore confirm the fragile, brittle and soft nature of moin-moin, as already suggested by the values for hardness and gumminess. The low values for adhesiveness (Table 4) indicate that mon-moin does not adhere to the palate.

Chewiness, representing the energy required for chewing solid foods to prepare for swallowing, is dependent on hardness, springiness and cohesiveness (Yuan et al., 2016). In this study, a good correlation between chewiness and hardness $(\mathrm{r}=0.992, \mathrm{p}=0.00)$, as well as gumminess $(\mathrm{r}=0.984 ; \mathrm{p}=0.00)$, was found. Due to the high variation in chewiness (Table 4), a similar variation in the time required to masticate a moin-moin piece prior to swallowing could be expected.

\section{Conclusion}

Moin-moin could be described as a soft, fragile and brittle food product. According to the high variability in all parameters determined, the preparation of moin-moin balls commercialized in Salvador (Bahia) lacks standardization in the ingredients used and in the process applied. In addition, the mean weight of a moin-moin ball varies considerably $(186.61 \mathrm{~g} \pm 29.74)$. The cowpea variety fradinho and crude palm oil or crude palm olein were identified as the major ingredients used. $\mathrm{CPO}$ and $\mathrm{CPOL}$ are responsible for the orange color of moin-moin and for their appreciable content of carotenoids (6.99 to $64.88 \mathrm{ppm}$ ). Thus, moin-moin can serve as an important source of pro-vitamin A, a micronutrient of public health significance in Salvador (Bahia). In addition, the consumption of a medium-sized moin-moin ball (186.6 g) meets $18.77 \%, 23.78 \%, 10.28 \%$ and $14.87 \%$ of the daily requirements of an adult for protein, lipid, carbohydrates and energy, respectively.

\section{Acknowledgements}

The authors are grateful for the financial support received from FAPESB (Fundação de Amparo à Pesquisa do Estado da Bahia), Process INT0012/2014, and Baianas de acarajé, for all cooperation.

\section{References}

Adekunte, A. O., Tiwari, B. K., Cullen, P. J., Scannell, A. G. M., \& O'Donnell, C. P. (2010). Effect of sonication on colour, ascorbic acid and yeast inactivation in tomato juice. Food Chemistry, 122(3), 500-507. http://dx.doi.org/10.1016/j.foodchem.2010.01.026.

Akajiaku, L. O., Nwosu, J. N., Odimegwu, E. N., Alagboso, S. O., \& Uzoechi, J. C. (2014). Influence of sprouted pigeon Pea (Cajanus Cajan) flour inclusion on sensory quality of moin-moin. The International Journal of Science \& Technoledge, 2(12), 122-129. Retrieved from http://internationaljournalcorner.com/index.php/ theijst/article/view/139817

Akusu, O. M., \& Kiin-Kabari, D. B. (2012). Protein quality and sensory evaluation of moin-moin prepared from cowpea/maize flour blends. African Journal of Food Science, 6(3), 47-51. http://dx.doi. org/10.5897/AJFS11.125.

Almeida, D. T., Viana, T. V., Costa, M. M., Silva, C. S., \& Feitosa, S. (2019). Effects of different storage conditions on the oxidative stability of crude and refined palm oil, olein and stearin (Elaeis guineensis). Food Science and Technology, 39(Suppl. 1), 211-217. http://dx.doi. org/10.1590/fst.43317.

Almeida, D. T., Nunes, I. L., Conde, P. L., Rosa, R. P. S., Rogério, W. F., \& Machado, E. R. (2013). A quality assessment of crude palm oil marketed in Bahia, Brazil. Grasas y Aceites, 64(4), 387-394. http:// dx.doi.org/10.3989/gya.118412.

Andreu-Sevilla, A., Hartmann, A., Sayas, E., Burló-Carbonell, F., Delgado-Estrella, P., Valverde, J. M., \& Carbonell-Barrachina, A. (2008). Mathematical quantification of total carotenoids in Sioma oil using color coordinates and multiple linear regression during deep-frying simulations. European Food Research and Technology, 226(6), 1283-1291. http://dx.doi.org/10.1007/ s00217-007-0656-2.

Association of Official Analytical Chemists - AOAC. (1995). Official methods of analysis of the Association of Official Analytical Chemists (16th ed.). Arlington: AOAC International.

Association of Official Analytical Chemists - AOAC. (1997). Official methods of analysis of the Association of Official Analytical Chemists (16th ed.). Washington: AOAC. 
Association of Official Analytical Chemists - AOAC. (2000). Official methods of the Association of the Agricultural Chemistry (Vol. 2, 17th ed.). Washington: AOAC.

Ayoade, F., Osho, A., Adesanya, O. O., Fayemi, O. S., Oyejid, N. E., \& Ojo, G. I. (2012). Effect of natural spices on the progression of microbial food spoilage in the steamed beans pudding, moin-moin. International Journal of Biological and Chemical Sciences, 6(6), 5030-5041. Retrieved from https://www.ajol.info/index.php/ijbcs/ article/view/88450

Borges, F. M. (2008). Acarajé: tradição e modernidade (Master's thesis). Universidade Federal da Bahia, Salvador. Retrieved from https:// repositorio.ufba.br/ri/bitstream/ri/8774/1/dissertacao_florismar.pdf

Brasil, Ministério da Saúde, Agência Nacional de Vigilância Sanitária - ANVISA. (2003, December 26). Regulamento técnico sobre rotulagem nutricional de alimentos embalados (Resolução RDC $\mathrm{n}^{\circ}$ 360, de 23 de dezembro de 2003). Diário Oficial [da] República Federativa do Brasil. Retrieved from http://portal.anvisa.gov.br/ documents/33880/2568070/res0360_23_12_2003.pdf/5d4fc7139c66-4512-b3c1-afee57e7d9bc

Brasil, Ministério da Saúde, Agência Nacional de Vigilância Sanitária ANVISA. (2005, September 23). Regulamento técnico sobre Ingestão Diária Recomendada (IDR) para proteína, vitaminas e minerais (Resolução RDC n 269, de 22 de setembro de 2005). Diário Oficial [da] República Federativa do Brasil (p. 372), seção 1. Retrieved from http://portal.anvisa.gov.br/documents/33916/394219/RDC_269_2005. pdf/2e95553c-a482-45c3-bdd1-f96162d607b3

Carvalho, A. F. U., Sousa, N. M., Farias, D. F., Rocha-Bezerra, L. C. B., Silva, R. M. P., Viana, M. P., Gouveia, S. T., Sampaio, S. S., Sousa, M. B., Lima, G. P. G. L., Morais, S. M. M., Barros, C. C., \& Freire, R., Fo. (2012). Nutritional ranking of 30 Brazilian genotypes of cowpeas including determination of antioxidant capacity and vitamins. Journal of Food Composition and Analysis, 26(1-2), 81-88. http:// dx.doi.org/10.1016/j.jfca.2012.01.005.

Charumanee, S., Yotsawimonwat, S., Sirisa-ard, P., \& Pholsongkram, K. (2017). Characterization and chemical composition of epicuticular waxfrom banana leaves grown in Northern Thailand. Songklanakarin Journal of Science and Technology, 19, 509. Retrieved from http:// rdo.psu.ac.th/sjstweb/Ar-Press/59-Aug/9.pdf

Chiaradia, A. C. N., \& Gomes, J. C. (1997). Feijão, química, nutrição e tecnologia. Viçosa: Fundação Arthur Bernardes.

Chinaza, U. P., Omotayo, O. A., Banji, A. F., Ololade, A. A., Olaoluwa, J. D., Adewale, O. A., Sarah, S. O., \& Grace, A. A. (2019). Nutritional investigation of three commonly consumed fast foods in two major fast food restaurants in Lagos State, Nigeria. Chemistry International, 5, 81-86. Retrieved from https://arabixiv.org/mpehc/

Ciabotti, S., Silva, A. C. B. B., Juhasz, A. C. P., Mendonça, C. D., Tavano, O. L., Mandarino, J. M. G., \& Gonçalves, C. A. A. (2016). Chemical composition, protein profile, and isoflavones content in soybean genotypes with different seed coat colors. International Food Research Journal, 23(2), 621-629. Retrieved from https://www.alice.cnptia. embrapa.br/handle/doc/1042920

Cushnie, T. P. T., \& Lamb, A. J. (2005). Antimicrobial activity of flavonoids. International Journal of Antimicrobial Agents, 26(5), 343-356. http:// dx.doi.org/10.1016/j.ijantimicag.2005.09.002. PMid:16323269.

Derivi, S. C. N., Mendez, M. H. M., Caldas, L. G. A., Toehwé, L. H., Almeida, C. B., \& Martins, D. V. (2006). Composição de caldos de feijões utilizados em dietas líquida. Higiene Alimentar, 20(139), 48-53. Retrieved from https://www.higienealimentar.com.br/wpcontent/uploads/2019/07/REVISTA-139.pdf

Enwere, N. J., \& Hung, Y.-C. (2000). Effect of cowpea seed and drying temperature and wet milling on the rheological properties of moin- moin paste and gel. Journal Tropical Agriculture, Food Environment Extension, 1(2), 42-51. http://dx.doi.org/10.4314/as.v1i2.1454.

Feitosa, S., Greiner, R., Meinhardt, A. K., Müller, A., Almeida, D. T., \& Posten, C. (2018). Effect of traditional household processes on iron, zinc and copper bioaccessibility in black bean (Phaseolus vulgaris L.). Foods, 7(8), 123. http://dx.doi.org/10.3390/foods7080123. PMid:30065167.

Feitosa, S., Korn, M., Pinelli, M., Oliveira, T., Boffo, E., Greiner, R., \& Almeida, D. (2015). Content of minerals and antinutritional factors in akara (Fried Cowpea Food). International Journal of Food Processing Technology, 2(2), 42-50. http://dx.doi.org/10.15379/24089826.2015.02.02.06.

Fernandes, A. C. (2010). Tipos de feijões e técnicas de preparo utilizados em unidades produtoras de refeições das regiões Sul e Sudeste do Brasil (Master's thesis). Universidade Federal de Santa Catarina, Florianópolis. Retrieved from https://repositorio.ufsc.br/xmlui/bitstream/ handle/123456789/93897/276834.pdf? sequence=1\&isAllowed $=y$

Fernandes, D. C., Souza, E. M., \& Naves, M. M. V. (2011). Feijão macerado: alternativa para melhorar a qualidade nutricional. Semina. Ciências Biológicas e da Saúde, 32(2), 177-184. http://dx.doi. org/10.5433/1679-0367.2011v32n2p177.

Food and Agriculture Organization - FAO. Codex Alimentarius. (2017). Codex standard for named vegetable oils (Codex STAN 210-1999). Rome. Retrieved from http://www.fao.org/fao-who-codexalimentarius/ sh-proxy/it/?lnk=1\&url=https\%253A\%252F\%252Fworkspace.fao. org\%252Fsites\%252Fcodex\%252FStandards\%252FCODEX\%2BST AN\%2B210-1999\%252FCXS_210e.pdf

Franco, G. (2008). Tabela de composição química de alimentos (9. ed.). São Paulo: Atheneu.

Frank-Peterside, N., Dosumu, D. O., \& Njoku, H. O. (2002). Sensory evaluation and proximate analysis of African yam bean (Sphenostylis stenocarpa Harms) moimoi. Journal of Applied Science \& Environmental Management, 6(2), 43. http://dx.doi.org/10.4314/jasem.v6i2.17175.

Goering, H. K., \& Van Soest, P. J. (1970). Forage fiber analysis: apparatus, reagents, procedures and some applications (Agricultural Handbook). Washington: Agricultural Research Service.

Gonçalves, A., Goufo, P., Barros, A., Domínguez-Perles, R., Trindade, H., Rosa, E., Ferreira, L., \& Rodrigues, M. (2016). Cowpea (Vigna unguiculata L. Walp) a renewed multipurpose crop for a more sustainable agri-food system: nutritional advantages and constraints. Journal of the Science of Food and Agriculture, 96(9), 2941-2951. http://dx.doi.org/10.1002/jsfa.7644. PMid:26804459.

Grune, T., Lietz, G., Palou, A., Ross, A. C., Stahl, W., Tang, G., Thurnham, D., Yin, S., \& Biesalski, H. K. (2010). $\beta$-Carotene is an important vitamin A source for humans. The Journal of Nutrition, 140(12), 2268S-2285S. http://dx.doi.org/10.3945/jn.109.119024. PMid:20980645.

Ikechukwu, A. G., Blessing, H., Chinyere, C. E., \& Ngozi, A. H. (2018). Physicochemical, microbial and sensory properties of MOI-MOI as affected by processing method. International Journal of Food Sciences and Nutrition, 3(5), 86-92. Retrieved from http://www. foodsciencejournal.com/archives/2018/vol3/issue5

Instituto Brasileiro de Geografia e Estatística - IBGE. (1999). Estudo nacional de despesa familiar: tabela de composição química de alimentos (5. ed.). Rio de Janeiro: IBGE. Retrieved from https:// biblioteca.ibge.gov.br/visualizacao/livros/liv50002.pdf

Instituto do Patrimônio Histórico e Artístico Nacional - IPHAN. (2005). Dossiê IPHAN 6: Ofício das Baianas do Acarajé. Retrieved from http://portal.iphan.gov.br/uploads/publicacao/PatImDos_ OficioBaianasAcaraje_m.pdf/ 
Jayathilake, C., Visvanathan, R., Deen, A., Bangamuwage, R., Jayawardana, B. C., Nammi, S., \& Liyanage, R. (2018). Cowpea: an overview on its nutritional facts and health benefits. Journal of the Science of Food and Agriculture, 98(13), 4793-4806. http://dx.doi.org/10.1002/ jsfa.9074. PMid:29656381.

Kethireddipalli, P., Hung, Y., Mcwatters, K., \& Phillips, R. (2002). Effect of milling method (wet and dry) on the functional properties of cowpea (Vigna unguiculata) pastes and end product (Akara) quality. Journal of Food Science, 67(1), 48-52. http://dx.doi. org/10.1111/j.1365-2621.2002.tb11357.x.

Khan, A. R. S., Alam, S., Ali, S., Bibi, S., \& Khalil, I. A. (2007). Dietary fiber profile of food legumes. Sarhad Journal of Agriculture, 23(3), 763-766. Retrieved from https://www.aup.edu.pk/sj_pdf/DIETARY\%20 FIBER\%20PROFILE\%20OF\%20FOOD\%20LEGUMES.pdf

Maidin, S., \& Latiff, A. N. (2015). Nasi Lemak packaging: a case study of food freshnbess and designe flexibility. Journal of Advanced Manufacturing Technology, 9(1), 13-19. Retrieved from https://jamt. utem.edu.my/jamt/article/view/279

Malomo, O., Apo, R., \& Adediran Alamu, E. (2017). Development of Spiced Instant 'Moinmoin" produced from precooked cowpea flour using maize starch as binder. International Journal of Food Science and Nutrition Engineering, 7(4), 75-90. http://dx.doi.org/10.5923/j. food.20170704.03.

Martínez-Delgado, A. A., Khandual, S., \& Villanueva-Rodríguez, S. J. (2017). Chemical stability of astaxanthin integrated into a food matrix: effects of food processing and methods for preservation. Food Chemistry, 225, 23-30. http://dx.doi.org/10.1016/j.foodchem.2016.11.092. PMid:28193419.

McWatters, K. H. (1983). Compositional, physical and sensory characteristics of Akara processed from cowpea paste and Nigerian cowpea flour. Cereal Chemistry, 60, 333-336. Retrieved from https:// www.cerealsgrains.org/publications/cc/backissues/1983/Documents/ chem60_333.pdf

Ogundele, G. F., Ojubanire, B., \& Bamidele, O. P. (2015). Proximate composition and organoleptic evaluation of cowpea (Vigna unguiculata) and soybean (Glycine max) blends for the production of Moi-moi and Ekuru (steamed cowpea paste). Journal of Experimental Biology and Agricultural Sciences, 3(2), 207-212. http://dx.doi. org/10.18006/2015.3(2).207.212.

Oguntona, C. R. B., Odunmbaku, J. A., \& Ottun, B. O. (1999). Proximate composition of ten standardized Nigerian dishes. Nutrition \& Food Science, 99(6), 95-302. http://dx.doi.org/10.1108/00346659910290466.

Organization for Economic Co-operation and Development - OECD. (2018). Consensus document on compositional considerations for new varieties of COWPEA (Vigna unguiculata): key food and feed nutrients, anti-nutrients and other constituents (Series on the Safety of Novel Foods and Feeds, No. 30). Paris. Retrieved from http:// www.oecd.org/officialdocuments/publicdisplaydocumentpdf/?cot $\mathrm{e}=$ env\%2Fjm\%2Fmono(2018)36\&doclanguage $=\mathrm{en}$

Ossai, G. E. A., Jowitt, R., \& Brennan, J. G. (1987). The effects of oil, egg and salt content on some physical properties of canned moinmoin. Journal of Food Engineering, 6(3), 231-239. http://dx.doi. org/10.1016/0260-8774(87)90027-6.

Otunola, G. A., \& Afolayan, A. J. (2018). Evaluation of the physicochemical, proximate, and sensory properties of moinmoin from blends of cowpea and water yam flour. Food Science \& Nutrition, 6(4), 991997. http://dx.doi.org/10.1002/fsn3.592. PMid:29983962.

Owuamanam, C. I., Edom, T. A., Ogueke, C. C., Iwouno, J. O., \& Olawuni, I. A. (2013). Quality characteristics of some tropical legume flours for steamed paste (moin moin) production as affected by seed sprouting. Asian Journal of Biological Sciences, 6(8), 347-355. http://dx.doi.org/10.3923/ajbs.2013.347.355.

Ribeiro-Silva, R. C., Nunes, I. L., \& Assis, A. M. O. (2014). Prevalência e fatores associados à deficiência de vitamina $\mathrm{A}$ em crianças $\mathrm{e}$ adolescentes. Jornal de Pediatria, 90(5), 486-492. http://dx.doi. org/10.1016/j.jped.2014.01.014. PMid:24886682.

Rodriguez-Amaya, D. B., \& Kimura, M. (2004). HarvestPlus handbook for carotenoid analysis (HarvestPlus Technical Monograph, No. 2). Washington: International Food Policy Research Institute (IFPRI) and International Center for Tropical Agriculture (CIAT). Retrieved from https://assets.publishing.service.gov.uk/ media/57a08cbae5274a31e00013d4/tech02.pdf

Rogério, W. F., Greiner, R., Nunes, I. L., Feitosa, S., Furtunato, D. M. N., \& Almeida, D. T. (2014). Effect of preparation practices and the cowpea cultivar Vigna unguiculata L.Walp on the quality and content of myo-inositol phosphate in akara (fried bean paste). Food Science and Technology, 34(2), 243-248. http://dx.doi.org/10.1590/fst.2014.0040.

Santos, V. J. R. (2013). O sincretismo na culinária afro-baiana: o acarajé das filhas de Iansã e das filhas de Jesus (Master's thesis). Universidade Federal da Bahia, Salvador. Retrieved from https://repositorio. ufba.br/ri/bitstream/ri/12689/1/Disserta\%c3\%a7\%c3\%a3o\%20 OK_Vagner\%20Rocha.pdf

Sanusi, R. A., \& Olurin, A. (2012). Portion and serving sizes of commonly consumed foods, in Ibadan, Southwestern Nigeria. African Journal of Biomedical Research, 15(3), 149-158. Retrieved from http://www. bioline.org.br/abstract?md12024

Shakpo, I. O., \& Osundahunsi, O. F. (2016). Effect of cowpea enrichment on the physico-chemical, mineral and microbiological properties of maize: cowpea flour blends. Research Journal of Food Science and Nutrition, 1(2), 35-41. http://dx.doi.org/10.31248/RJFSN2016.007.

Singh, N., Kaur, M., Sandhu, K. S., \& Sodhi, N. S. (2004). Physicochemical, cooking and textural characteristics of some Indian black gram (Phaseolus mungo L) varieties. Journal of the Science of Food and Agriculture, 84(9), 977-982. http://dx.doi.org/10.1002/jsfa.1744.

Singh, N., Singh, J., Kaur, L., Singh Sodhi, N., \& Singh Gill, B. (2003). Morphological, thermal and rheological properties of starches from different botanical sources. Food Chemistry, 81(2), 219-231. http:// dx.doi.org/10.1016/S0308-8146(02)00416-8.

Souza, C. O., Menezes, J. D. S., Ramos, D. C. No., Assis, J. G. A., Silva, S. R., \& Druzian, J. I. (2012). Total carotenoids and vitamin A of cucurbits from germoplasma bank of Embrapa Semiarido. Ciência Rural, 42(5), 926-933. http://dx.doi.org/10.1590/S0103-84782012005000024.

Universidade Estadual de Campinas - UNICAMP. (2011). TACO: tabela brasileira de composição de alimentos (4th ed.). Campinas: NEPAUNICAMP. Retrieved from http://www.nepa.unicamp.br/taco/ contar/taco_4_edicao_ampliada_e_revisada.pdf?arquivo=taco_4_ versao_ampliada_e_revisada.pdf

Van Soest, P. J., Robertson, J. B., \& Lewis, B. A. (1991). Methods for dietary fiber, neutral detergent fiber and non-starch polysaccharides in relation to animal nutrition. Journal of Dairy Science, 74(10), 3583-3597. http://dx.doi.org/10.3168/jds.S0022-0302(91)78551-2. PMid:1660498.

Yuan, C., Du, L., Zhang, G., Jin, Z., \& Liu, H. (2016). Influence of cyclodextrins on texture behavior and freeze-thaw stability of kappacarrageenan gel. Food Chemistry, 210(1), 600-605. http://dx.doi. org/10.1016/j.foodchem.2016.05.014. PMid:27211687. 